\title{
Accounting for Co-operative purposes: reclaiming the conversation. Concept paper on a SORP for co-operatives
}

\author{
Maureen McCulloch, Senior Lecturer, Oxford Brookes Business School and Instructor, Co-operative \\ Management Education Programme, Saint Mary's University
}

\begin{abstract}
Co-operatives, built on mutuality, present a challenge to the dominant paradigm of the investororiented business. It is difficult, if not impossible, to understand and explain co-operative activities properly in the language of returns on financial investment. This paper argues that we need to develop an accounting which facilitates understanding co-operatives on their own terms; an accounting which would allow cooperatives to reclaim the conversation about the sort of society we want to build together from the debates about returns on investment.

This paper sets out to explore and champion the possibility of the co-operative movement developing a specifically co-operative oriented format for financial accounting and reporting which would allow cooperatives to differentiate themselves from both investor-oriented businesses and philanthropic organisations: a statement of recommended practice (SORP) in accounting and reporting for co-operatives. Reporting under such a SORP would allow co-operatives to recognise their fundamental principles of participation, mutuality, democracy and community through membership as opposed to investor supremacy or philanthropy whilst still complying with international financial reporting standards (IFRS).
\end{abstract}

This paper uses the SORP in accounting and reporting for charities in the UK as an example of how a very different approach to accounting (concentrating on the organisational purpose) can be, and actually is, accommodated under IFRS in order to explore what can be learnt for co-operatives.

Maureen McCulloch is Senior Lecturer in Accounting in the Oxford Brookes Business School, UK and an instructor in the Co-operative Management Education Programme at Saint Mary's University. Her research focuses on accounting for non-profit and social enterprises including co-operatives. Prior to joining the staff at Oxford Brookes Business School, Maureen was finance director for a number of non-profit organisations, consultant for several others and a visiting lecturer at several UK universities covering accounting for purposes other than profit. Maureen is a Chartered Accountant (UK) and is currently completing her PhD at Sheffield Business School.

Keywords: co-operative accounting, Statement of Recommended Practice, IFRS, membership

\section{Introduction}

Co-operatives, built on mutuality, present a challenge to the dominant paradigm of the investor-oriented business. It is difficult, if not impossible, to understand and explain co-operative activities properly in the language of capitalism. This paper argues that we need to develop an accounting which facilitates understanding co-operatives on their own terms; an accounting which would allow co-operatives to reclaim the conversation about the sort of society we want to build together from the debates about returns on investment (Holloway, 2010).

This paper sets out to explore and champion the possibility of the co-operative movement developing a specifically co-operative oriented format for financial accounting and reporting that would allow co-operatives to differentiate themselves from both investor-oriented businesses and philanthropic organisations: a Statement of Recommended Practice (SORP) in Accounting and Reporting for Co-operatives. Reporting under such a SORP would allow cooperatives to recognise their fundamental principles of participation, mutuality, democracy and community through membership as opposed to investor supremacy or philanthropy whilst still complying with International Financial Reporting Standards (IFRS).

Correspondence address: Maureen McCulloch, Senior Lecturer, Oxford Brookes Business School and Instructor, Cooperative Management Education Programme, Saint Mary's University. mmcculloch@brookes.ac.uk 
The paper builds on the work of the Centre of Excellence in Accounting \& Reporting for Co-operatives at Saint Mary's University, Canada (see Appendix 1). It uses the SORP in Accounting and Reporting for Charities in the UK as an example of how a very different approach to accounting (concentrating on the organisational purpose) can be, and actually is, accommodated under IFRS in order to explore what can be learnt for co-operatives.

The paper concentrates on financial accounting and reporting. There are many initiatives to develop specifically cooperative performance indicators and any format for financial statements developed for co-operatives would need to be compatible with these (see Appendix 2) but that is, for the moment, outside the scope of the project outlined in this paper.

\section{What is a co-operative?}

A co-operative is

an autonomous association of persons united voluntarily to meet their common economic, social, and cultural needs and aspirations through a jointly owned and democraticallycontrolled enterprise. (ICA, 1995)

Co-operation is first and foremost about people coming together to meet common aspirations and needs; that a business enterprise is involved and that the business might need financial capital are ancillary. (Chieh \& Weber, ICA, 2016:16)

he joint stock company is a union of money units, each of which carries a vote. The co-operative society is a union of persons. These persons do not, like the shareholders in a joint stock bank, join together to earn a profit out of others. (Wolff 1907:50 cited in Birchall 2010:3)

\section{What is a SORP?}

SORPS are sector-driven recommendations on financial reporting, auditing practices or actuarial practices for specialised industries, sectors or areas of work, or which supplement FRC (Financial Reporting Council) standards and other legal and regulatory requirements in the light of special factors prevailing or transactions undertaken in that particular industry, sector or area of work that are not addressed in FRC standards. SORPs also address matters that are addressed in FRC standards, but about which additional guidance is considered necessary. When there are policy options in FRC standards, a SORP may recommend the most appropriate option to the particular industry or sector. (FRC, 2018:3, emphasis added).

Currently in the UK there are several sectors which use a SORP - further and higher education, authorised funds, social housing, limited liability partnerships, investment trust companies and venture capital trusts, pension schemes and charities. This paper will discuss the charity SORP as an example of how accounting and reporting for purposes other than profit can be accommodated in UK legislation and under IFRS.

Although the UK's Co-operatives and Community Benefit Societies Act 2014 is supposed to formally unite cooperatives, many are set up as limited companies and consequently report to Companies House while others are registered charities and report to the Charity Commission. Co-operatives currently find themselves accounting and reporting under formats designed either for commercial investor-oriented businesses or for philanthropic organisations. Neither format takes the membership-based co-operative purpose and principles into account. This makes it difficult for co-operatives to demonstrate, even to members, how different their purposes and modus operandi are to those of companies who seek primarily to make returns for their financial investors or to those of charities who are legally required to apply their resources to the benefit of others. 
The argument of this paper is that co-operatives need a SORP for two main reasons. The first is that they currently cannot use their financial statements to demonstrate and explain how the financial aspects of their activities tie into and support their co-operative purposes. The second, which follows from the first, is that they are invisible qua cooperatives under our current accounting rules, being classed either as investor-driven or philanthropic.

\section{Current situation}

Currently we have two possible accounting formats for organisations which are not part of government - for-profit financial reporting for investor-oriented organisations and not-for-profit financial reporting for philanthropic organisations. The perspectives behind these formats are very different from one another, demonstrating that the format of financial statements can be adapted to better serve the potential users of those statements even under IFRS.

Figure 1 illustrates how social enterprises including co-operatives sit between organisations that are entirely commercially motivated and those that are entirely for public benefit.

\section{Figure 1}

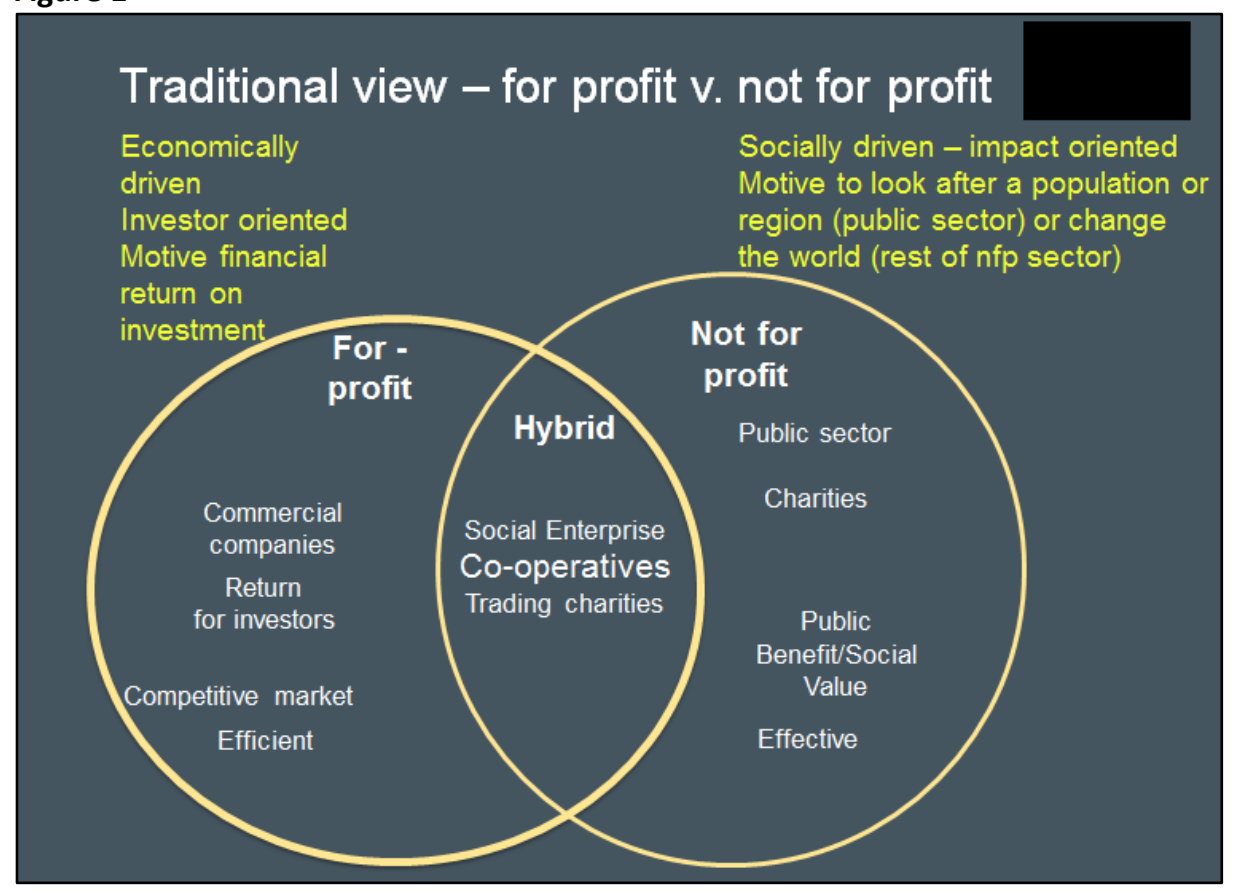

Nicholls (2010) argues that the two paradigms - for-profit and not-for-profit - are fighting it out in the hybrid area of social enterprise. However, the not-for-profit format is at a disadvantage because it is defined in terms of the dominant paradigm (Gray et al, 2006) not on its own terms. This paper argues (using charities as an example) that not-for-profit accounting is better understood as accounting for-purpose. The real distinction should not be between for-profit and not-for-profit but between the pursuit of "returns to equity" and the pursuit of "purposes beyond returns to equity". The need for an accounting format which allows for purposes beyond "return on investment" is common to the entire social economy. It is potentially an area where co-operatives could lead amongst organisations in the social economy.

However, co-operatives are at a further disadvantage. They are a special case within social enterprises because they adhere to the co-operative purposes and principles based on mutuality. Co-operative accounting needs to be accounting specifically for co-operative purposes which, it could be argued, are not just hybrids of commercial and philanthropic objectives but are fundamentally different from the two approaches we already have, based as they are on mutual interest and benefit. 
Maureen McCulloch

Unless they are registered as non-profit distributing public benefit entities, co-operatives adopt the for-profit format. If they are registered as for public benefit, they adopt the not-for-profit/charity format. Reporting in different formats, each designed for organisations with different purposes to co-operatives, obscures the membership-based co-operative purpose and splits the co-operative economy, making it harder to recognise and understand as a whole.

This binary opposition can be seen at work in the recent debates about how to classify the social economy for National Accounts purposes. The definition put forward by Salamon \& Sokolowski (2018), which is to be adopted by the UN Handbook on Nonprofit Institutions in the System of National Accounts, broadened to cover the social economy as well as the third sector, uses the absence of profit distribution as a proxy for public benefit. This definition of the social economy draws a line directly through the co-operative movement placing those that allow profit distribution to members in the commercial field and those that do not in the social economy. The repercussion is that the co-operative economy will be split in National Accounts and therefore much harder to see, study or legislate for as a whole.

The argument developed here is not that co-operatives should adopt charity accounting but that co-operatives should argue for an accounting format which recognises the cooperative (as opposed to charity/philanthropic) purposes and modus operandi beyond the pursuit of return on financial investment.

Because of the difficulties other social enterprises (e.g. mutuals, B Corps) face in tying their financial statements to their social purposes, and because purpose is defined by each organisation in its own way through its aims and objectives and, as such, is generalised, co-operatives might be able to work with other parts of the social economy on developing a for-purpose SORP. This would indeed be a way to challenge, and maybe eventually change, the dominant investor-oriented paradigm.

\section{For-profit and for-purpose (not-for-profit) accounting}

This section comprises a brief history of the bodies responsible for the different types of accounting based on the UK experience (within the European Union) and a second section which looks at the differences between for-profit and not-for-profit accounting. The argument is made that not-for-profit accounting is better understood as forpurpose accounting. Understood as for-purpose accounting, it can offer a model upon which a format for accounting for co-operatives that recognises the co-operative principles might be negotiated as acceptable under International Financial Reporting Standards.

\section{For-profit financial reporting - International Accounting Standards Board}

The International Accounting Standards Committee (IASC) was established in 1973 to oversee the project of harmonising financial reporting globally. The project was, from the outset, concerned with companies whose shares are traded publicly through stock exchanges, i.e., listed companies. In 2001 the IASC was replaced by the International Accounting Standards Board (IASB). The IASB adopted the International Accounting Standards that had been issued by the IASC and developed them into International Financial Reporting Standards (IFRS). The IASB also started a project to develop a conceptual framework to underpin and give coherence to the work on issuing accounting standards. This conceptual framework explicitly states that the primary purpose of financial reporting is to give information to current and potential financial investors. The IASB sees the main users of financial reports as:

present and potential investors, lenders and other creditors, who use that information to make decisions about buying, selling or holding equity or debt instruments and providing or settling loans or other forms of credit. [F OB2] (IASB, 2010:9).

It is, therefore, not at all surprising that co-operatives have great difficulty fitting into the IFRS format. These difficulties mostly turn on definitions of equity, membership and participation and what corporate performance is and how it should be measured, which for IFRS are financially based and defined purely from an investor perspective. The fundamental assumptions about the identification of the primary readers of the statements (shareholders or 
participating members) and what they want the information for are different because the organisational purposes are so different.

The IASB is a private, not-for-profit corporation operating as the technical arm of the IFRS Foundation. It has a board of fourteen experts in accounting for listed companies, public markets and large banks, drawn from practice and academia. The IASB develops and reviews IFRS, which are then adopted by countries through national legislation or as stock exchange regulation governing conditions which listed companies must meet. The European Union adopts IFRS automatically since agreeing to do so in 2005. In the UK, IFRS feeds into company law through the convergence of UK Generally Accepted Accounting Practice (GAAP) with IFRS under the auspices of the Financial Reporting Council (FRC), which took over responsibility for UK accounting standards from the Accounting Standards Committee (ASC) in 2012. The FRC is currently under review (Kingman, 2018).

\section{For-purpose (not-for-profit) financial reporting - the Charities SORP Committee}

In a survey for the Institute of Chartered Accountants in England \& Wales (ICAEW), Bird and Morgan-Jones (1981) concluded that reporting by charities in the UK was not at all consistent, even amongst those charities which fell under the Companies Acts and consequently under company accounting regulation. They concluded that a unified approach to charity accounting that allowed for how different charities are from commercial companies was needed. In response, the ASC set up a working party to look into charity accounting and the first recommendations, as regards standardising charity accounts with an emphasis on charities' public benefit objectives, were released in 1988.

The responsibility for drawing up the charity SORP devolved to the SORP committee of the charity regulator, the Charity Commission in England \& Wales, in 1990, so subsequent SORPs have been drawn up by this committee and agreed by the ASC, which has now been replaced by the FRC. The SORP became the Statement of Recommended Practice, Accounting and Reporting for Charities in 2000 in recognition of the growing importance of the narrative explanation of the figures within charity accounting (Hyndman \& McMahon, 2010).

The SORP Committee is the technical committee operating under the auspices of the Charity Commission drawing up, regularly reviewing and issuing guidance on implementation of the SORP for charities. Like the IASB, it is made up of experts drawn from practice and academia, but, for the charity SORP committee, they are experts in accounting for charities. Since the development of IFRS, the SORP Committee regularly reviews charity accounting to ensure that it is still compatible with IFRS and negotiates this with the FRC. The Charity SORP committee is recognised as a "SORP-making body" by the FRC. Charity Financial Statements which comply with the SORP are acceptable under IFRS.

The charity SORP feeds into UK legislation through charity law. This means that complying with the charity SORP is not voluntary in the UK. Organisations which are registered as charities must comply with the core of the SORP. Guidance from the Charity Commission indicates which parts are voluntary and which are compulsory. Failure to comply can result in de-registration with the concomitant loss of the tax advantages available to charities.

\section{Charity accounting as accounting for purpose}

In order to register as a charity in the UK, an organisation must demonstrate that it is set up for "public benefit". The benefit must be to the public or a section of the public, and any private benefit must be incidental. The charity must set out its objectives on registration and review them regularly. The Financial Statements under the SORP are designed to show how charity resources have been raised and used in pursuit of the charity's aims and objectives. Whilst it is obviously true that charity accounts under the SORP are not-for-profit, this description misses the essential point about them, which is that they are designed to demonstrate how financial resources have been raised and used to fund activities to achieve the charity's purpose. Co-operatives need an accounting format which will allow them to demonstrate how resources have been raised and applied through and towards fulfilment of cooperative purposes. 
Appendix 3 shows extracts from the Financial Statements of the National Trust (NT), a member-based organisation, one of the largest charities in the UK, described at Co-operatives Congress in 2011, by the then CEO, Fiona Reynolds, as a "co-operative in all but ownership". The NT Financial Statements show how the organisation's resources have been used in pursuit of the NT's purpose.

The Profit and Loss Account of a commercial company is replaced in a charity by a Statement of Financial Activities that sets out how resources have been raised - through fundraising or trading in order to support the main activities of the organisation, or through the main activities themselves, which in many cases, as here with the NT, are based on trading with members and non-members. It also shows how the resources have been used - which activities they have supported. For justification of the activities (their relationship with the purposes of the organisation and their effectiveness in achieving the objectives), we have to go into the narrative reports and non-financial indicators. These Financial Statements can accommodate multiple purposes recognising how

some purposes (fundraising to support the main purposes for instance) can be subsidiary. They recognise that finance is subsidiary in itself - that the purposes of the organisation are primarily non-financial; finance is a tool to help achieve them, as noted by Chieh \& Weber above.

The for-profit format is designed to show the financial impact of the organisation's activities. The not-for-profit format sends the reader out from the financial statements for justification of the ways in which resources are raised and used - to see how effectively the funds have been applied to change the world in the direction agreed in the charity's objectives, its purpose. This is why it is argued that this sort of accounting is better understood as forpurpose.

The Balance Sheet of the NT is similar to the Statement of Financial Position (SFP) for commercial companies as regards assets and liabilities, but the Equity/Capital part of the SFP is replaced by a section covering the Funds carried forward. This section can also accommodate share capital as evidenced in the Balance Sheet of Greenwich Leisure Limited (GLL) (Appendix 4), a worker-controlled co-operative with exempt charity status.

\section{Co-operatives and the potential of for-purpose accounting}

The following section is offered as suggestions for how co-operatives could potentially apply the concept of forpurpose accounting. The ideas are quite embryonic. They require development.

If co-operatives were to adopt a for-purpose format for their Financial Statements, they could set out the cooperative purposes of their organisation as embodied in the areas of activity in which they would be raising and to which they would be applying funds. To do this, they would need to clearly map the co-operative principles against the activities in the narrative accompanying the report.

One of the main problems co-operatives face when accounting under the for-profit format in IFRS is the classification of members' equity. If the equity is withdrawable, it must be classed as a liability for the co-operative, thereby eroding the ownership base and making co-operatives appear more financially fragile than they actually are. This treatment of members' funds also serves to separate the co-operative as an entity from part of its membership.

Charity accounting - as demonstrated in the previous section - concentrates on the purposes for which financial resources have been raised and to which they are applied. It goes further, classifying financial resources (funds) themselves by purpose. It divides funds into those that can be used for any purpose agreed by the organisation within its aims and objectives and those that are restricted to specific uses. For charities, restricted funds are characterised by conditions imposed by the external donor while unrestricted funds are those which the charity can use for any activity covered by its purposes. Within unrestricted funds, the charity itself can designate certain funds for specific purposes. If co-operatives were to adopt a form of co-operative fund accounting, restricted funds would be those whose use is restricted by external forces, such as legislation. Designated funds would be those the cooperative has set aside for specific purposes by its own decree - which would be decided through the democratic governance process within the co-operative - and could therefore cover discretionary withdrawable funds. General unrestricted funds would be whatever does not fall into the other two strands. 
It is possible for charities to account in this way because they do not have to deal with the question of ownership in the Balance Sheet. Nonetheless, the funds section of the Balance Sheet plus long-term liabilities (which would be amounts owed to non-members) would still represent the capital employed, as can be seen from the GLL example (Appendix 4). The funds section would represent the members' financial interest in the co-operative, and this could be analysed between indivisible, non-withdrawable and withdrawable. Fund accounting allows for a more nuanced categorisation than the overly simplistic division into equity or liability. Little thought has, as yet, been given to a for-purpose approach to co-operative accounting. Much more research is needed into the potential of for-purpose fund accounting for co-operatives and how this might address the equity/liability problem posed under IFRS.

Fund accounting might also address the problem of distinguishing between member participation and trade with non-members by splitting the Statement of Financial Activity (SoFA) into Members' Participation Funds and General Funds. So, the revenue raised from operating facilities in the NT SoFA could be split on the face of the SoFA into Members' Participation and trading with non-members.

\section{Practical Research Agenda to develop a SORP for co-operatives}

Much work has already been done by the Centre of Excellence in Accounting and Reporting for Co-operatives at Saint Mary's University in Halifax, Nova Scotia, Canada on the problems co-operatives encounter under IFRS and, based on this, the possible content of an international SORP for co-operatives. This paper is arguing for a Cooperative SORP which is designed to account for co-operative purposes not just as a reaction to investor-oriented accounting, but as a vehicle to articulate co-operative purposes and distinctiveness, both to the co-operative movement itself and to wider society.

More research is needed into how the perspective of for-purpose accounting might inform a co-operative SORP as well as the ongoing research into the problems that are caused for co-operatives under IFRS designed for investororiented organisations. Research is also needed into the practicalities of the proposition of developing a cooperative format which would be acceptable under IFRS - as the UK charity SORP is.

It is suggested that a co-ordinated, two-pronged approach be pursued at the international and national level continued research into an international SORP, and a practical programme to develop a UK Co-operative SORP that would be acceptable under IFRS and could eventually be incorporated in UK legislation in the same way as the UK Charity SORP is. This suggestion is made because the framework for formulating and adopting SORPs, parts of which are legally binding, is well developed in the UK and accepted under IFRS. Developing a UK co-operatives SORP would be a way to work within the space allowed for negotiation under IFRS and within a tradition which is used to undertaking such negotiations.

The UK SORP could, then, act as a base (recognised as acceptable under IFRS) for international co-ordination of cooperative accounting. The UK charity SORP is closely aligned with Generally Accepted Accounting Practice for notfor-profits and there is currently a movement developing towards international alignment of national practices in not-for-profit accounting (Crawford et al., 2018). In practice, the international SORP would be international Generally Accepted Accounting Practice guidelines for co-operatives, which would be aligned with the UK SORP if the two projects are well co-ordinated as both are developed.

The international research would continue to be co-ordinated by CEARC and would inform the work of a committee of experts within the UK, which would need to be set up with the agreement and under the auspices of the FRC, as a "SORP-making body" to work towards the development and adoption of a UK SORP for Co-operatives. It should be recognised that the development of a co-operative SORP will take several years (at least five) and require at least some funding. 


\section{Practicalities}

The FRC will consider authorising the development of a SORP in support of FRC standards if the circumstances warrant it, for example if one or more of the following factors are present:

(a) there are indications that issuing a SORP will lead to higher quality financial reporting, auditing or actuarial work or conversely a risk of unacceptable quality if a SORP is not issued;

(b) there is evidence or a risk of inconsistent practice across different entities overall or within a particular industry leading to an unacceptable lack of comparability;

(c) there is an industry or sector specific need;

(d) changes within a particular industry or sector mean that an FRC standard requires additional application guidance; or

(e) there is a recognised need in the public interest to establish a benchmark for accountability of professionals. (FRC, 2018:4)

It can be argued that there is a clear need for a SORP-making body to research accounting for co-operatives under headings $a, b$ and $c$ above, and possibly under $d$. These arguments need to be compiled and presented to the FRC and other interested bodies (see below).

It is very important that the proposed SORP committee is representative of the UK Co-operative sector.

The FRC may recognise bodies for the purpose of developing and issuing SORPs. Bodies will only be recognised where the following criteria are met:

(a) the industry or sector represented by the body in question has special financial reporting, auditing or actuarial issues and the application or interpretation of FRC standards requires clarification in order to deal with those issues;

(b) the body in question represents the whole or a major part of the industry or sector;

(c) the body shares the FRC's aim of: (i) high-quality financial reporting proportionate to the size and complexity of the entity and users' information needs; or (ii) high-quality auditing work proportionate to the needs, size and complexity of the entity; or (iii) highquality actuarial work.

(d) the body agrees to abide by this Policy in developing its SORP;

(e) the body commits to reviewing its SORP in line with this Policy; and

(f) when an industry or sector is regulated or financed by another body, the regulator or financing body has confirmed in writing that it is content for the body seeking recognition by the FRC as a SORP-making body to promulgate SORPs for that industry or sector. (FRC, 2018: 5, emphasis added)

It is also imperative that the proposed SORP committee discusses the project with, and gains the agreement of, the regulators who currently oversee the different areas which may be covered by the new SORP, currently the FCA and the Charity Commission. The agreement of the FRC is required before a body starts to develop a SORP. 
It is worth noting that the Kingman Report, a review of the FRC (2018), concentrates on the FRC's role as the audit and actuarial regulator, notes only in passing that the FRC has a responsibility for accounting standards and fails to mention SORPs at all. This would indicate that the responsibility for SORPs is rather peripheral for the FRC.

\section{Proposition}

It is proposed that Co-ops UK, as the umbrella body for UK co-operatives, would be the lead organisation for the development of a UK Co-operatives SORP.

The initial feasibility study comprises several strands which need to be undertaken simultaneously. The steps suggested are:

a) To undertake a survey similar to that conducted by Bird \& Morgan-Jones in 1981 on charity accounting for the ICAEW, on co-operative accounting within the UK. The support of co-operatives and maybe that of the Employee Ownership Association should be sought. It may be advantageous to involve the main accountancy bodies as well if possible.

b) As part of the survey, or maybe building on the results, to canvass opinion in the wider co-operative movement about the relevance of the project.

c) To open a dialogue with the FCA and FRC about establishing a co-operative SORP committee and setting its terms and remit. The UK government has recently promised to explore how to improve regulatory clarity for societies and Community Interest Companies through non-legislative means. Clarifying accounting standards would contribute to this work.

d) Find suitable people prepared to serve on the committee. It is suggested that the committee should draw members from the co-operative accounting world, ensuring a balance of those used to dealing with IFRS and those used to dealing with reporting under the charity SORP. It should also include, if possible, even if only as advisers, people with experience of developing the charity SORP.

e) Draw up an activity plan for the project and establish how to fund it adequately over the several years it will take to achieve its objectives. Ideally, this work would be funded mostly by the UK co-operative movement, but it may be possible to obtain grant funding for some of it.

\section{Conclusion}

Co-operative accounting under IFRS cannot adequately demonstrate the use of resources in pursuit of the membership-based co-operative purposes and modus operandi. For-purpose accounting, as in the charity SORP in the UK, obscures co-operative principles because it concentrates on "public benefit" understood as altruistic benefit for others. However, the idea of for-purpose accounting and the use of a SORP to allow for different purposes could be a useful model for co-operatives to explore in developing a way of accounting which can make the co-operative difference (mutuality and participation) clear.

A co-operative SORP is necessary for accounting for co-operative purposes to be acceptable under IFRS, which is automatically adopted throughout the EU including the UK. Research has already started into the possibility of an international SORP for co-operatives. It is suggested that a two-pronged approach be adopted, one focused on developing a UK SORP for accounting and reporting for co-operatives using the way that charities account for very different purposes as a model, and another strand that continues to develop international support for international alignment of co-operative accounting. The two strands should collaborate so that developments are aligned.

The first steps of the UK strand would be to undertake a survey of the current state of co-operative accounting within the UK and then to establish support for the project researching a potential SORP. It is suggested that Co-operatives UK, as the umbrella body for the UK, play the lead role in this phase of the project. 


\section{Maureen McCulloch}

\section{References}

Birchall, J., 2010. People Centred Business: The History of Co-operatives and Mutuals in the UK. Basingstoke, UK: Palgrave MacMillan.

Bouchard, M.J., Le Guernic, M. and Rousselière, D. (2017), 'Conceptual Framework for the Purpose of Measurement of Cooperatives and its Operationalization'. Report for the International Labour Office.

Chieh \& Weber, 2016, Editors' Forward, The Capital Conundrum for Co-operatives, International Co-operative Alliance

Crawford, L., Morgan, G.G. and Cordery, C.J., 2018. Accountability and not-for-profit organisations: Implications for developing international financial reporting standards. Financial Accountability \& Management, 34(2), pp.181-205.

Gray, R., Bebbington, J. and Collison, D., 2006. NGOs, civil society and accountability: making the people accountable to capital. Accounting, Auditing \& Accountability Journal, 19(3), pp.319-348.

Holloway, J. 2010. Crack Capitalism. Pluto Press, London.

Hyndman, N. and McMahon, D., 2010. The evolution of the UK charity Statement of Recommended Practice: The influence of key stakeholders. European Management Journal, 28(6), pp.455-466.

Kingman, 2018. Financial Reporting Council: review 2018 available at https://www.gov.uk/government/publications/financial-reporting-council-review-2018

Salamon, L.M. and Sokolowski, W. (2018), 'Beyond non-profits: in search of the third sector. In The Third Sector As A Renewable Resource for Europe (pp. 7-48). Palgrave Macmillan. 


\section{Appendix 1}

It should be noted that this paper is not the first attempt to develop a co-operative SORP. In fact, the Centre of Excellence in Accounting and Reporting (CEARC), over the period 2007 to 2011, developed the following SORPs to provide guidance on a wide array of issues:

- $\quad$ iSORP 1 - Objectives, scope and purpose

- $\quad$ iSORP 2 - Reporting co-operative members' funds

- $\quad$ iSORP 3 - Reporting payments to members

- $\quad$ iSORP 4 - Reporting on membership

- $\quad$ iSORP 5 - Environmental sustainability reporting guidelines

- $\quad$ iSORP 6 - Discussion Paper - Co-operative non-financial reporting

https://www.smu.ca/academics/sobey/cearc-isorp-project.html 


\section{Appendix 2}

'Non-financial' or performance reporting also plays an important role in telling the full story of a co-operative's performance. There are several co-operative performance reporting projects that are currently ongoing that focus on the wider co-operative performance outcomes. For example, CoopsUK has recently introduced a narrative reporting initiative which focuses on three main areas:

- Member value: how it is delivering value to its members

- Member voice: how its members have directed the co-op

- Co-operative values: how it is living up to the co-operative values

The narrative reporting framework provides guidance on how co-ops might structure their annual report to members, and also includes a framework through which co-ops can view their wider communications with members throughout the year. The essence of narrative reporting is reflected in Figure 2 (https://www.uk.coop/newsroom/new-framework-and-guidance-help-co-ops-report-members).

\section{Figure 2: Narrative Reporting: The Framework}

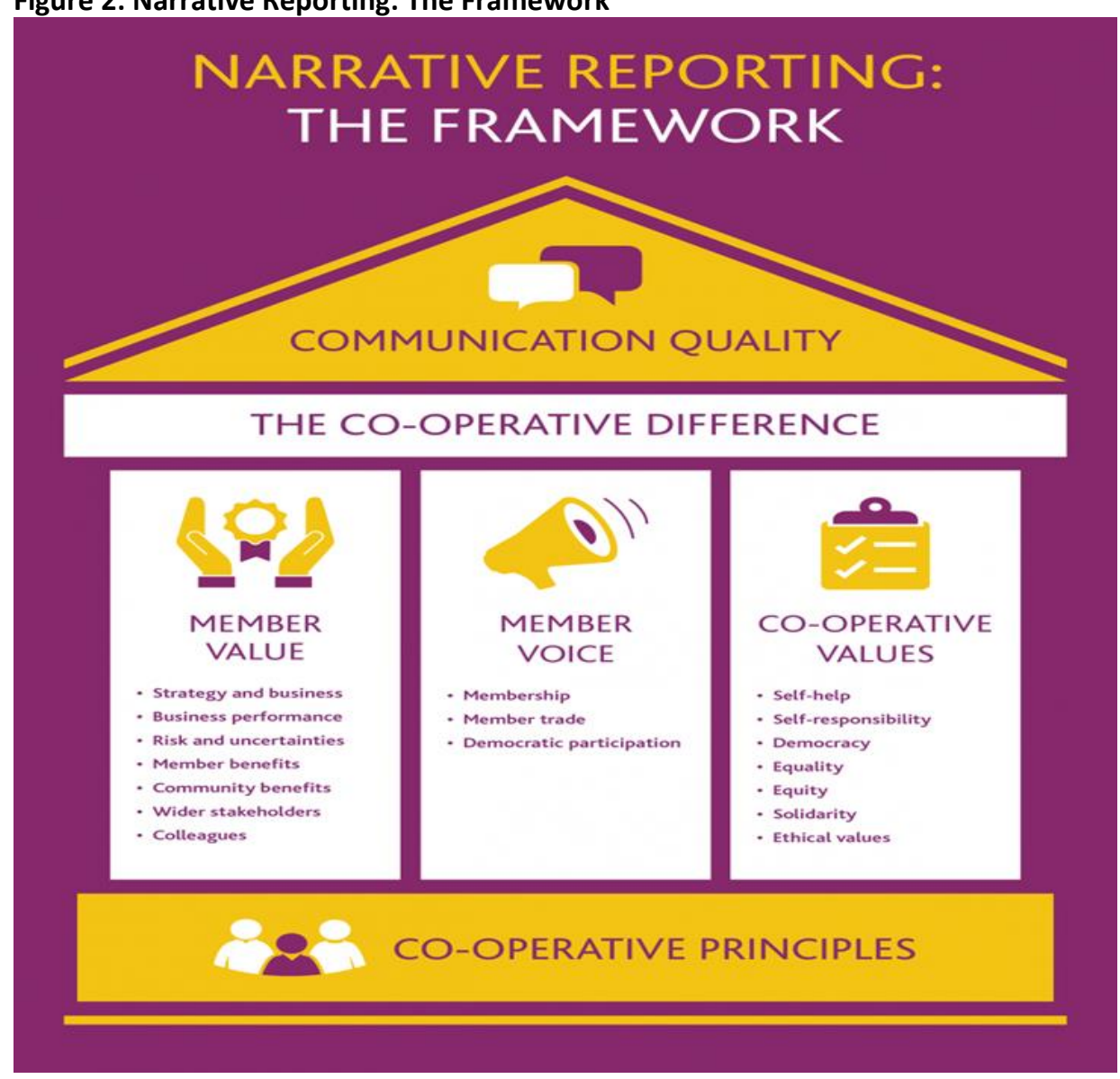

Another example of a co-operative reporting framework is the Co-operative Performance Indicators (CPI) project led by the Centre of Excellence in Accounting and Reporting for Co-operatives, based at Saint Mary's University, Nova Scotia, Canada. The CPI is currently in the pilot phase and its focus is to develop a series of measures that reflect the seven principle of co-operatives. The ultimate aim of the CPI is to develop benchmark data that will enable cooperatives to compare and evaluate their performance (https://www.smu.ca/academics/sobey/co-operativeperformance-indicators.html). 


\section{Appendix 3}

\section{National Trust Consolidated Statement of Financial Activities y/e 28 ${ }^{\text {th }}$ Feb 2018}

$\begin{array}{cccccc}\text { Unrestricted } & \text { Restricted } & \text { Endowment } & \text { Total } & \\ \text { Funds } & \text { Funds } & \text { Funds } & 2018 & 2017 \\ & f^{\prime} 000 & f^{\prime} 000 & f^{\prime} 000 & f^{\prime} 000 & f^{\prime} 000\end{array}$

Income and endowments from:

Donations and legacies

Appeals and gifts

$1,815 \quad 11,366$

$13,181 \quad 11,525$

Legacies

Operating grants and contributions

$33,944 \quad 17,876$

118

51,938

61,693

115

5,706

5,821

6,144

Other trading activities

Enterprise and renewable energy income

73,412

73,412

72,852

Hotel income

\begin{tabular}{rrrrr}
73,412 & & & 73,412 & 72,852 \\
& 8,368 & & 8,368 & 8,135 \\
6,962 & 8,291 & 13,914 & 29,167 & 25,540 \\
\hline 116,248 & 51,607 & 14,032 & 181,887 & 185,889 \\
\hline
\end{tabular}

\section{Charitable activities}

Membership income

Project grants and contributions

Direct property income

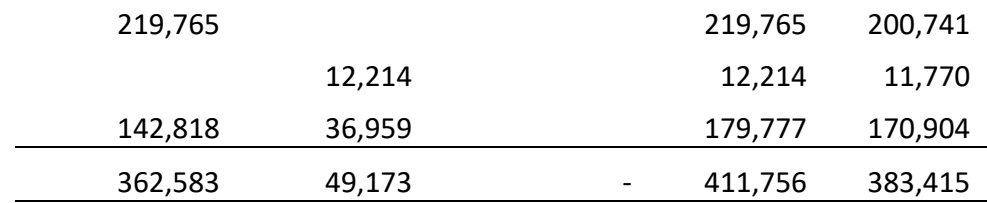

Other

Other income

Total income

\begin{tabular}{rrrrr}
631 & 531 & 70 & 1,232 & 22,438 \\
\hline $\mathbf{4 7 9 , 4 6 2}$ & $\mathbf{1 0 1 , 3 1 1}$ & $\mathbf{1 4 , 1 0 2}$ & $\mathbf{5 9 4 , 8 7 5}$ & $\mathbf{5 9 1 , 7 4 2}$ \\
\hline
\end{tabular}

Raising funds

Fundraising costs

Enterprise and renewable energy costs

\begin{tabular}{rrrrr}
3,601 & & & 3,601 & 3,315 \\
52,642 & & & 52,642 & 53,832 \\
& 8,226 & & 8,226 & 8,066 \\
1,798 & 1,974 & 3,523 & 7,295 & 5,522 \\
\hline 58,041 & 10,200 & 3,523 & 71,764 & 70,735 \\
\hline
\end{tabular}

\section{Charitable activities}

Property operating costs

Expenditure on property projects

Acquisitions

Internal conservation and advisory services

Membership costs

\begin{tabular}{rrrrr}
208,506 & 69,722 & & 278,228 & 255,611 \\
83,758 & 54,586 & 41 & 138,385 & 139,304 \\
8,031 & 3,434 & & 11,465 & 10,030 \\
50,993 & 1,536 & & 52,529 & 46,183 \\
52,883 & 205 & & 53,088 & 45,543 \\
\hline 404,171 & 129,483 & 41 & 533,695 & 496,671 \\
\hline
\end{tabular}


Net (expenditure)/income before gains on investments

\begin{tabular}{rrrrr}
17,250 & $(38,372)$ & 10,538 & $(10,584)$ & 24,336 \\
15,103 & 17,252 & 30,722 & 63,077 & 190,302 \\
\hline $\mathbf{3 2 , 3 5 3}$ & $\mathbf{( 2 1 , 1 2 0 )}$ & $\mathbf{4 1 , 2 6 0}$ & $\mathbf{5 2 , 4 9 3}$ & $\mathbf{2 1 4 , 6 3 8}$ \\
\hline
\end{tabular}

Net income

$$
4,341
$$

17,710

$(22,051)$

Actuarial gains/(losses) on defined benefit pension scheme

$$
83,592
$$

Net movement in funds

Fund balances brought forward

Fund balances carried forward

\begin{tabular}{rrrrr}
120,286 & $(3,410)$ & 19,209 & 136,085 & 119,774 \\
\hline 189,720 & 473,665 & 581,495 & $1,244,880$ & $1,125,10$ \\
& & & & 6 \\
\hline $\mathbf{3 1 0 , 0 0 6}$ & $\mathbf{4 7 0 , 2 5 5}$ & $\mathbf{6 0 0 , 7 0 4}$ & $\mathbf{1 , 3 8 0 , 9 6 5}$ & $\mathbf{1 , 2 4 4 , 8 8}$ \\
\hline
\end{tabular}




\section{Appendix 4}

GREENWICH LEISURE LIMITED

FIXED ASSETS

Intangible assets

Tangible assets

Investments

Investment property

\section{CURRENT ASSETS}

Stocks

Debtors (within one year)

Debtors (longer than one year)

Cash at bank and in hand

\section{CREDITORS}

Amounts due within one year

NET CURRENT ASSETS

TOTAL ASSETS LESS CURRENT

LIABILITIES

CREDITORS

Amounts due after one year

NET ASSETS EXCLUDING PENSION LIABILITY

PENSION LIABILITY

FUNDS

Unrestricted funds

Designated funds

Total unrestricted funds

Restricted funds

Share Capital

TOTAL FUNDS

TOTAL FUNDS EXCLUDING PENSION LIABILITY

CONSOLIDATED BALANCE SHEET AT 31ST December 2017

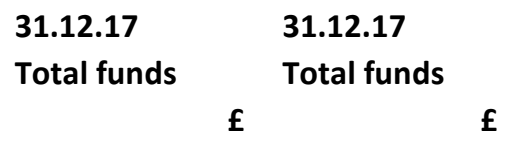

325,833

$56,412,858$

12

$1,003,090$

$57,741,793$

504,625

$38,607,219$

$6,908,622$

$22,725,435$

$68,745,901$

$(69,667,876)$

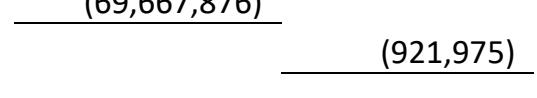

$56,819,818$

$(20,666,227)$

$36,153,591$

$43,334,000$

$(8,034,169)$

395,481
31.12.16

Total funds

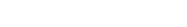

31.12.16

Total funds

f

423,572

$57,230,641$

12

$1,200,869$

$58,855,094$

520,753

$29,809,897$

$7,573,816$

$\frac{21,597,312}{59,501,778}$

$(57,285,266)$

$2,216,512$

$61,071,606$

$(26,395,923)$

$34,675,683$

$45,149,000$

$(11,443,207)$

411,296

$(7,638,688)$

414,779

43,500

$(7,180,409)$

$36,153,591$
$(11,031,911)$

516,409

42,425

$(10,473,077)$

$34,675,923$ 